JEL: F31

DOI: 10.5937/industrija41-3522

Original Scientific Paper

\title{
Testing of empirical grounds for theoretical models of real exchange rate: research of real exchange rate between RSD and Euro ${ }^{2}$
}

\author{
Article history: \\ Received 28 February 2012 \\ Sent for revision 28 August 2012 \\ Received in revised form 04 February 2013 \\ Accepted 26 Mart 2013 \\ Available online 23 April 2013
}

\begin{abstract}
The focus of this research holds the most important determinants of real exchange rate covered by various theoretical models. The empirical testing was carried out on the real exchange rate between RSD and Euro for the period from January 2007 to December 2010, which was significantly imposed by availability of consistent time series. The research pertains to five basic model specifications and is based on the testing of time series cointegration by applying Johansen and Engle-Granger's test. The obtained results have shown that the observed models do not have grounds in empirical data. Time series figuring in models are not cointegrated, and besides that, the estimated cointegration coefficients have signs opposite to the expected ones in large number of cases. In our opinion, the reasons for such findings can be found in the fact that used time series are quite short, i.e. they pertain to the period of only four years, as well as that prices of some significant services are still under the administrative control. Still, despite the aforementioned lacks, we think that our findings can be accepted as preliminary knowledge about the ability of the observed models to explain the dynamics of real exchange rate between RSD and Euro.
\end{abstract}

Keywords: real exchange rate, real interest rates, net international investment position, fiscal saldo, relative labour productivity.

\footnotetext{
${ }^{1}$ Dr Predrag Petrović, Research Associate, Institute of Social Sciences (http://www.idn.org.rs/), Kraljice Natalije 45, 11000 Belgrade P. O. BOX 605, Republic of Serbia, Scientific affiliation: International Economics and Macroeconomics, Phone: +38111361 6001, E-mail: ppetrovic@idn.org.rs

${ }^{2}$ The paper presents the results of a study conducted as part of the project III47010: Social Transformation in the process of European integration - a multidisciplinary approach, funded by the Ministry of Education and Science, Republic of Serbia, 2011-2014.
} 
Petrović: Testing of empirical grounds for theoretical models of real exchange rate...

\section{Introduction}

The analysis of effects of monetary and financial fundamental variables to exchange rate is one of inevitable topics for researchers in this field (Jaewoo \& Tang, 2003, p. 3). One of the basic determinants, impact of which is almost always in focus of interest, is surely the differential of real interest rates (Byrne \& Nagayasu, 2010). A long-term equilibrium relation between the real exchange rate and real interest rates differentials can be obtained based on conventional equilibrium conditions often seen in literature related to international finances. More precisely, the uncovered interest parity and Fisher's hypothesis make the cornerstone of theoretical relation between the real exchange rate and real interest rates. Authors of numerous studies have tended to reveal and prove the existence of equilibrium relation based on this approach, which generated various results (Byrne et al., 2010, p. 2). For example, Hoffmann and MacDonald (Hoffmann \& MacDonald, 2006) present robust empirical evidence about statistical significance of the relation real exchange rate - real interest rate, although recognising that support for this causality is, overall, quite weak.

A specific angle of analysing the determinants of real exchange rate is testing of different variant of Balassa-Samuelson (BS) model (Bayram, 2007). There are several reasons why the BS model has become so popular in transitional countries over the past twenty years (Tica \& Družić, 2006, p. 4). One reason is surely the formation of a rich database and fast development of econometric techniques necessary for the implementation of comprehensive empirical researches. However, in addition to the mentioned reasons, it is deemed that the process of the European Union (EU) enlargement is far most important event which affected the increase of research interest for the BS model.

The EU enlargement process generated certain dilemmas with respect to consequences of the BS effect in the accessing countries. Actually, the core of the problem is the impact which may be generated by faster growth of productivity in the accessing countries with respect to productivity in member states of the European Monetary Union (EMU) to fulfilment of nominal criteria of convergence covered by the Maastricht Treaty. This potential problem has particularly attracted attention of researchers at the end of 1990s, exactly at the time of approximation of transitional countries from Central and Eastern Europe to full EU membership. If this problem really exists, then the question is brought up whether trade off between the real convergence and the EMU membership is inevitable.

The analysis of the role of distribution sector deserves specific attention, since this analysis has been neglected within the standard BS model, and very few 
authors have researched its impact to the real exchange rate. MacDonald and Ricci (MacDonald \& Ricci, 2001, MacDonald \& Ricci, 2005) emphasised the importance of disaggregation of productivity into three sectors: sector of tradable goods, sector of non-tradable goods and distribution sector. Such decomposing enables careful consideration of the role which labour productivity in distribution sector plays in the formation of dynamics of real exchange rate. On the other hand, Timmer and Inklaar (Timmer \& Inklaar, 2005) deem that researches conducted in the area of economic relations between the leading countries of the world quite commonly overestimate the value of productivity differential in distribution sector, hence leading to the position that conclusions about its impact to the real exchange rate are unreliable.

The BS effect was not interesting for the economists in the area of the EU enlargement only. A great deal of literature is dedicated to the impact of the production differential to the exchange rate between Euro and Dollar. Using different indicators for aggregate productivity, Alquist and Chinn (Alquist \& Chinn, 2002) have revealed the effect of productivity to the dynamics of the real exchange rate between Euro and Dollar. Yet, lack of this analysis is seen in the use of aggregate productivity indicators, which does not enable testing of the original BS effect.

Discussion about the impact of productivity to appreciation of Dollar with respect to Euro was particularly motivated by the fact that faster growth of average productivity in the USA and slowing down thereof in the EMU was recorded in the second half of 1990s. Bailey, Millard and Wells (Bailey, Millard \& Wells, 2001) deem that structural improvements of productivity in the USA increased the rate of productivity to the capital, and it caused its massive inflow which can explain at least a part of significant appreciation of Dollar. In addition, Tille, Stoffels and Gorbatchev (Tille, Stoffels, \& Gorbatchev, 2001) have empirically confirmed the thesis that dynamics of relative labour productivity can explain a part of change in Dollar exchange rate over the past three decades. Camarero, Ordóñez and Tamarit (Camarero, Ordóñez, \& Tamarit, 2002) provide for evidence about the dependence of real exchange rate between Euro and Dollar on the import of oil, differential of real interest rates and relative productivity in the sector of non-tradable goods (closed sector). Schnatz, Vijselaar and Osbat (Schnatz, Vijselaar, \& Osbat, 2004) have shown that dynamics of relative labour productivity can explain only a part of depreciation of real exchange rate between Euro and Dollar, where share of such part depends on productivity indicator used during the research.

Empirical testing of standard BS effect has led to confronted opinions. While there is a considerable consensus about the long-term impact of relative labour productivity in the open sector (sector of tradable goods) to relative prices of non-tradable goods on one hand, still there are numerous controversies 
Petrović: Testing of empirical grounds for theoretical models of real exchange rate...

with regard to the impact of differences in relative labour productivity in the open sector between different countries to discrepancy in their overall inflation and real exchange rate on the other (De Broeck \& Slok, 2001, Égert, 2002, Halpern \& Wyplosz, 2001).

In this paper, we have addressed researches of determinants of real foreign exchange rate between RSD and Euro in the period between January 2007 and December 2010, by testing sustainability of several theoretical models covering almost all most important explanatory variables suggested by theory. We started the testing by exploring the impact of differentials of real interest rates, which was followed by gradual extension of the model by including differentials of net international investment position (NIIP), indicators of relative labour productivity (in the open, closed and distribution sectors) and differential of fiscal saldo.

This paper has been made in four parts. The first one is actually the setting of methodological framework which is the basis of our research. In the second and third parts, respectively, we have exposed the most significant information about data and manner of certain variables structuring, as well as the results of empirical analysis with related discussion. The final part of the paper includes the most important conclusions.

\section{Methodological framework}

Theoretical model which served as a basis for empirical research incorporates the most important determinants of real exchange rate found in literature. The real exchange rate has been defined as (Camarero, 2008, p. 622):

$$
q_{t}=-e_{t}+p_{t}-p_{t}^{*}
$$

where $e_{t,} p_{t}$ and $p_{t}^{*}$ respectively denote logarithm transformations of nominal exchange rate (number of monetary units of domestic currency for one monetary unit of a foreign currency), level of prices in domestic country and level of prices in a foreign country. The rise (fall) of such structured real exchange rate indicates its appreciation (depreciation). If we assume that: (a) real exchange rate gets back to equilibrium status in a constant rate after the external shock, (b) that long-term equilibrium real exchange rate is a non-stationary variable, and (c) that uncovered parity of real interest rates has been met, the exchange rate equation can be formulated as: 
Petrović: Testing of empirical grounds for theoretical models of real exchange rate...

$$
q_{t}=\varphi\left(R_{t}-R_{t}^{*}\right)+\widehat{q}_{t}
$$

where $R_{t}$ and $R_{t}^{*}$ respectively mean domestic and foreign real interest rates, while $\hat{q}_{t}$ means a long-term equilibrium real exchange rate (Camarero, 2008, p. 622). Such approach implies the need to determine the most important determinants of $\hat{q}_{t}$. There is no doubt that according to theory, dynamics of a long-term equilibrium real exchange rate should be shaped by differences in productivity, fiscal saldo and net international investment position between the countries.

In order to reach the above stated gradually, it was necessary to start from the equation (1.1) which we used to structure real exchange rate based on general level of prices (for tradable and non-tradable goods) in the domestic and foreign country. The real exchange rate also can be formulated by the means of prices for tradable goods, i.e. as follows:

$q_{t}^{T}=-e_{t}+p_{t}^{T}-p_{t}^{T^{*}}$

where $T$ shows that this variable pertains to tradable goods. At the same time, general levels of prices contained in equation (1.1) can be shown as:

$$
\begin{aligned}
& p_{t}=\left(1-\alpha_{t}\right) p_{t}^{T}+\alpha_{t} p_{t}^{N T}, \\
& p_{t}^{*}=\left(1-\alpha_{t}^{*}\right) p_{t}^{T *}+\alpha_{t}^{*} p_{t}^{N T *},
\end{aligned}
$$

where $\alpha_{t}$ and $\alpha_{t}^{*}$ respectively mean a share of non-tradable goods in GDP of domestic and foreign country, while NT means non-tradable goods. By replacing (1.3), (1.4) and (1.5) in (1.1), we obtain the following equation of a longterm real exchange rate:

$$
\widehat{q}_{t}=q_{t}^{T}-\alpha_{t}\left(p_{t}^{T}-p_{t}^{N T}\right)+\alpha_{t}^{*}\left(p_{t}^{T *}-p_{t}^{N T *}\right)
$$

Equation (1.6) indicates two potential sources of variability of long-term real exchange rate. The first source surely is the differential of relative prices for non-tradable goods with respect to tradable goods between domestic and 
foreign country, which is actually the first part of external transmission mechanism of the BS model. In the BS model, the starting point is the assumption that growth in labour productivity in the open sector most commonly higher than the growth in productivity in the closed sector (Égert, Drine, Lommatzsch, \& Rault, 2002, pp. 3-7). Perfect mobility of workers between the sectors is also assumed, which leads to equal sectoral wages. Increase in labour productivity in the open sector reduces its unit costs for labour and enables proportional increase of wages without influencing the labour unit costs. If we represent that costs and prices of other production inputs remain unchanged, it is clear that overall unit costs will remain the same, so cost pressures to growth in prices for tradable goods will be omitted. Growth of wages in the open sector, taking into account perfect mobility of labour, will influence increase in wages in the closed sector. If growth in labour productivity of the closed sector does not follow the pace of the growth in labour productivity in the open sector, the increase of wages will put pressure to the increase of absolute and relative prices for non-tradable goods. If observed at international level, faster growth of labour productivity in the domestic country compared to a foreign one will lead to higher inflation in the domestic country. If change in nominal exchange rate, according to the assumptions of the BS model, covers the discrepancy between the growth of domestic and foreign prices for tradable products, higher domestic inflation, caused by increase in prices for non-tradable goods, will lead to appreciation of real exchange rate based on the consumer prices index.

When testing the BS effect, there is a need to pay specific attention to distribution sector, which imposes the derivation of completely different theoretical model (MacDonald et al., 2005, pp. 7-9). The labour productivity in distribution sector has two-sided (positive and negative) impact to the real exchange rate. Such effect comes out of the fact that distribution sector has a twofold function: (a) it supplies the open sector with intermediary goods (so it can be observed as a part of the open sector), and (b) supplies tradable goods to final consumers, due to which it is treated as a part of the service (closed) sector. The net impact will depend on whether the role of distribution sector is larger in the first or second case.

The other source of oscillations in a long-term balanced real foreign exchange rate is related to the abandoning of the assumption on constant status of real exchange rate structured based on prices for tradable goods. Changes in the real exchange rate for tradable goods are primarily influenced by fiscal policy, effect of which can be considered in different ways. Expansive character of fiscal policy and growth in state deficit force the government to get indebted, which, according to Mundell-Fleming's model, reduces the national savings and offer of capita, increasing domestic real interest rates and putting the 
Petrović: Testing of empirical grounds for theoretical models of real exchange rate...

pressure on appreciation of foreign exchange rate. Opposite to this, the portfolio balance models are based on the fact that permanent fiscal expansion increases international obligations and reduces net international investment position, causing depreciation of foreign exchange rate. Ganelli (Ganelli, 2005 ) is of the opinion that these two standpoints to impact of fiscal policy can reconcile by accepting the opinion that fiscal expansion causes a short-term appreciation in the exchange rate, while, in the long run, through net international investment position, it influences its depreciation. Besides the public expenditures (savings), the foreign exchange rate is also influenced by private savings. Taking this into account, it is clear that differential of rates in private savings is surely mirrored to the net international investment position.

Taking into account all the stated determinants, the general model could be shown as (Camarero, 2008, p. 624):

$$
\begin{aligned}
& q_{t}=\varphi\left(R_{t}-R_{t}^{*}\right)+\widehat{q}_{t}= \\
& =f\left(\left(R_{t}-R_{t}^{*}\right),\left(a_{t}^{T}-a_{t}^{T *}\right),\left(a_{t}^{N T}-a_{t}^{N T *}\right),\left(a_{t}^{D}-a_{t}^{D *}\right),\left(g_{t}-g_{t}^{*}\right), d n f a_{t}\right)
\end{aligned}
$$

where $\left(a_{t}^{T}-a_{t}^{T *}\right)$ means the differential in productivity in the open sector, while $\left(a_{t}^{N T}-a_{t}^{N T *}\right)$ and $\left(a_{t}^{D}-a_{t}^{D *}\right)$ respectively denote equivalents for the closed and distribution sector; $\left(g_{t}-g_{t}^{*}\right)$ means the differential of fiscal saldo, while $d n f a_{t}$ stands for relative net international investment position of a country.

Our empirical research is based on general specifications of equations composed of several simple theoretical models, which include various combinations of explanatory variables. Therefore, the subject of econometric testing is the following models (Camarero, 2008, p. 624-625):

a) $L N R E R 1_{t}=C+\beta_{1} R S 2_{t}+\varepsilon_{t}$,

b) $\quad L N R E R 1_{t}=C+\beta_{1} R S 2_{t}+\beta_{2} D N F A_{t}+\varepsilon_{t}$, 
Petrović: Testing of empirical grounds for theoretical models of real exchange rate...

c) $\quad L N R E R 1_{t}=C+\beta_{1} R S 2_{t}+\beta_{2}$ LNAIRPOT $_{\mathrm{t}}+\beta_{3} \mathrm{LNAIRPZA}_{\mathrm{t}}+\beta_{4} \mathrm{LNAIRPD}_{\mathrm{t}}+\varepsilon_{\mathrm{t}},(10)$

d) LNRER1 $_{t}=C+\beta_{1} F S_{t}+\beta_{2}$ LNAIRPOT $_{\mathrm{t}}+\beta_{3}$ LNAIRPZA $_{\mathrm{t}}+\beta_{4} \mathrm{LNAIRPD}_{\mathrm{t}}+\varepsilon_{t}$

e)
$=C+\beta_{1} F S_{t}+\beta_{2} R S 2_{t}+\beta_{3}$ LNAIRPOT $_{t}+\beta_{4}$ LNAIRPZA $_{t}+\beta_{5}$ LNAIRPD $_{\mathrm{t}}+\varepsilon_{t}$

where LNRER1 stands for real exchange rate; RS2 - differential of real interest rates; DNFA - differential of net international investment position; FS differential of fiscal saldo; LNAIRPOT, LNAIRPZA and LNAIRPD - relative labour productivity in the open, closed and distribution sector respectively.

\section{Data}

Empirical testing of determinants of real foreign exchange rate was conducted for the period between January 2007 and December 2010, primarily due to availability and consistency of data. All important information about time series and manner of structuring of certain variables is provided for in Table 1. 


\section{Table 1 - Variables we used in the empirical testing}

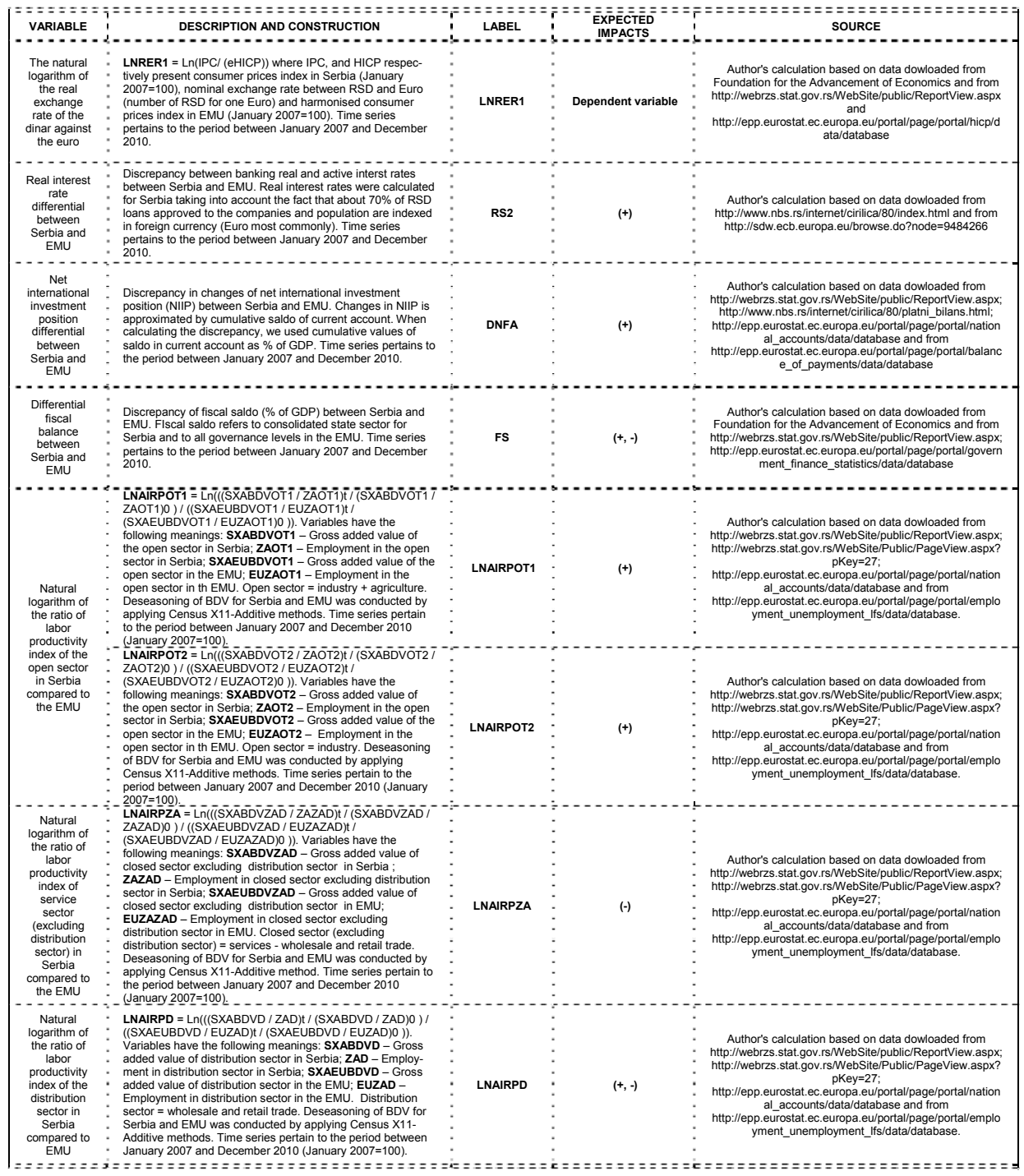

Note: Disaggregation of time series was performed with program package ECOTRIM, applying Boot, Feibes, Lisman methods, minimising the sum of squared first differences of disaggregated time series.

Source: Author 
Petrović: Testing of empirical grounds for theoretical models of real exchange rate...

We have structured time series of the real exchange rate between RSD and Euro by employing consumer prices index for Serbia and harmonised consumer prices index in EMU. The consumer prices index has been in existence in Serbia since 2007. Average weighed real interest rates to total placement of banks in Serbia are partially corrected by changes in foreign exchange rate, taking into account that about $70 \%$ of RSD placements to the companies and population are indexed in foreign currency, primarily in Euros. Net international investment position has been included in the analysis as a cumulative of current account saldo. Actually, such approach, according to balance of payments identities, quantifies the changes in NIIP (Camarero, 2008, p 631). Fiscal saldo pertains to consolidated public sector in Serbia and to all level of governance in the EMU. Bearing in mind that literature does not contain a generally accepted method for classification of economic sectors to open and closed ones (Égert, et al., 2002, p. 8), we have classified them in two ways. Firstly, we treated industry and agriculture as open sectors, while services were classified as non-tradable goods. The other way implies elimination of agriculture from the analysis process, so that only industrial products remain as tradable goods, whereat services have unchanged status. We obtained average labour productivity by dividing seasonally adjusted sectoral gross value added with overall number of employees in the given sector.

\section{Results of empirical testing}

Before starting the formal testing, we had analysed the dispersion diagram of real exchange rate between RSD and Euro with respect to each determinant (Figure 1). The visual analysis reveals that foreign exchange rate either does not demonstrate any correlation with other variables, or that direction of correlation is completely opposite to the expected ones. Namely, correlation with respect to relative labour productivity in the open sector is in both cases unexpectedly negative and high $(-0.79$ and -0.51$)$. In addition, correlation with differential NIIP is, contrary to theory, negative and quite high (-0.67). At the same time, when it is about relative labour productivity in the closed and distribution sectors and differential of fiscal saldo, the correlation is of expected direction, but is quite low, especially in the case of fiscal saldo $(-0.29,-0.35$ and -0.03 , respectively). The only determinant fulfilling the expectations is the differential of real interest rates, which is highly positively correlated with foreign exchange rate $(0.71)$. 
Petrović: Testing of empirical grounds for theoretical models of real exchange rate...

Figure 1 - Dispersion diagrams of real exchange rate with respect to other variables
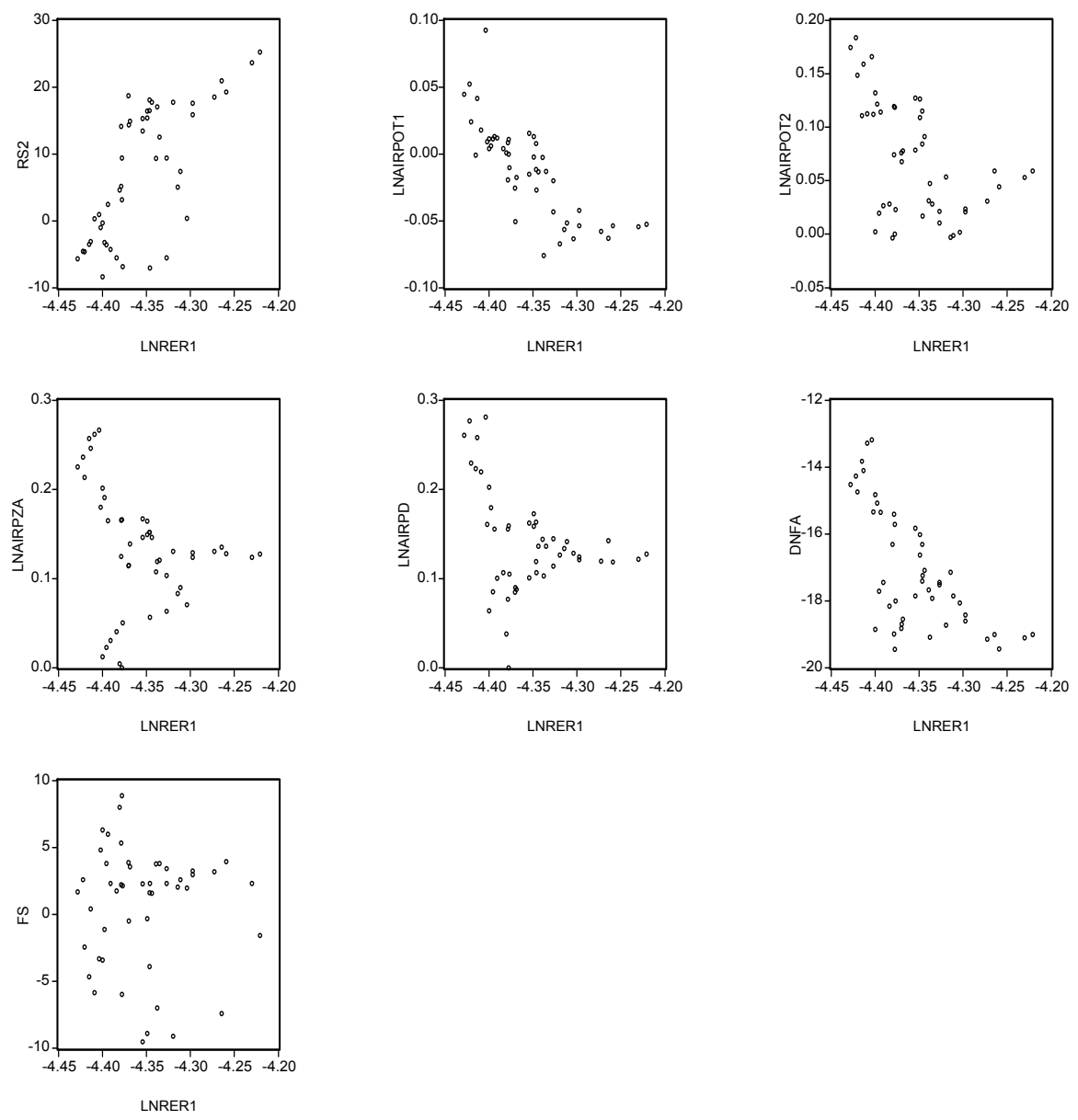

Source: Author

We initiated the formal research by testing no-stationarity of time series using Dickey-Fuller and Phillips-Perron's test, which has shown that these are I(1) processes (test results are available at request). Non-stationarity of time se- 
Petrović: Testing of empirical grounds for theoretical models of real exchange rate...

ries indicates the conclusion that cointegration analysis is a suitable methodological framework for our research.

Table 2 - Results of econometric test: Engle-Granger's test

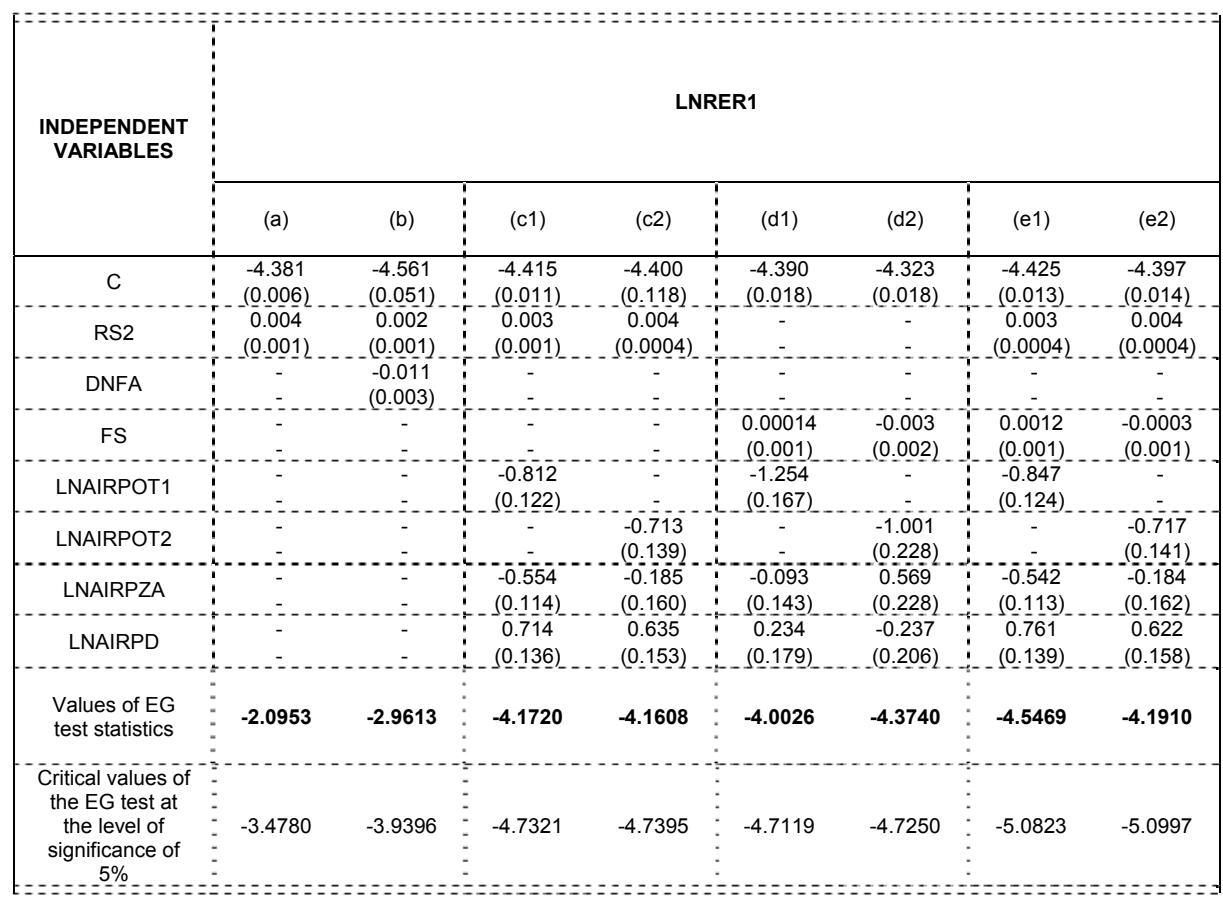

Note: Detailed results of cointegration tests are available on request. Critical values of the EG test are obtained according to James. G. MacKinnon (2010). Standard errors are given in parentheses below the coefficients. Econometric analysis was carried out by applying program package EViews 3.1.

Source: Author

The results of the Engle-Granger's (EG) test shown in Table 2 have shown that none of tested specifications [(a)-(e)] has empirical support. In all cases at $5 \%$ significance level, we accept a zero hypothesis that time series are not cointegrated. Besides, the obtained cointegration coefficients quite commonly are not in accordance with theoretical expectations. Namely, according to our results, the growth in relative productivity in the open sector, regardless of its definition, should influence depreciation of real exchange rate, which is completely contrary to the $B S$ model. Illogical effect can also be attributed to relative labour productivity in the closed sector (model d2) and to differential NIIP 
Petrović: Testing of empirical grounds for theoretical models of real exchange rate...

(model $b$ ). One variable which has the expected sign in all specifications is the differential of real interest rates. Based on the stated, we can conclude that results of the $E G$ test are to great extent correspond to expectations based on visual analysis of the dispersion diagram.

Using the Johansen's test of cointegration, we have obtained similar results (Table 3). Still, we have not exposed all the analyses this time. The reason for such approach is the fact that Johansen's test reveals the existence of a number of cointegration equations for $c$-e models, which do not correspond to our specifications, and do not have theoretical support. In other words, by applying the Johansen's test, we have not managed to assess the equations which are equivalent to our models in terms of specification, but they are completely different and comprise various combinations of explanatory variables. Since our goal was to test empirical grounds of a-e models, we deem that there is no sense in showing these results.

Table 3 - Results of econometric testing: Johansen's test

\begin{tabular}{|c|c|c|}
\hline \multirow[t]{2}{*}{ INDEPENDENT VARIABLES } & \multicolumn{2}{|c|}{ LNRER1 } \\
\hline & (a) & (b) \\
\hline $\mathrm{C}$ & $\begin{array}{c}-4.382 \\
(0.01556)\end{array}$ & $\begin{array}{c}-4.430 \\
(0.09333)\end{array}$ \\
\hline RS2 & $\begin{array}{c}0.004 \\
(0.00126)\end{array}$ & $\begin{array}{c}0.003 \\
(0.00088)\end{array}$ \\
\hline 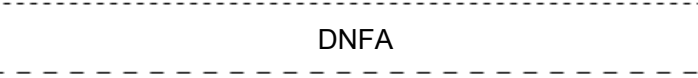 & $-{ }_{-}^{-}-$ & $\begin{array}{l}-0.004 \\
(0.05 \underline{0} 9)\end{array}$ \\
\hline $\begin{array}{l}\text { Critical values at the level of significance of } 5 \% \text { (Ho: no } \\
\text { cointegration equation) }\end{array}$ & 19.96 & 34.91 \\
\hline $\begin{array}{l}\text { Values of LR test statistics } \\
\text { (Ho: no cointegration equation })\end{array}$ & 10.35 & 28.22 \\
\hline $\begin{array}{l}\text { Critical values at the level of significance of } 5 \% \text { (Ho: at } \\
\text { most one cointegration equation) }\end{array}$ & 9.24 & 19.96 \\
\hline $\begin{array}{l}\text { Values of LR test statistics } \\
\text { (Ho: at most one cointegration equation) }\end{array}$ & $\begin{array}{r}2.88 \\
----\end{array}$ & $\begin{array}{r}9.82 \\
---\end{array}$ \\
\hline $\begin{array}{l}\text { Critical values at the level of significance of } 5 \% \text { (Ho: at } \\
\text { most two cointegration equation) }\end{array}$ & - & 9.24 \\
\hline $\begin{array}{l}\text { Values of LR test statistics } \\
\text { (Ho: at most two cointegration equation) }\end{array}$ & - & 2.12 \\
\hline
\end{tabular}

Note: Detailed results of cointegration tests are available on request. Standard errors are given in parentheses below the coefficients. Econometric analysis was carried out by applying program package EViews 3.1.

Source: Author 
Petrović: Testing of empirical grounds for theoretical models of real exchange rate...

As for the first two models $(a-b)$, the obtained values of the trace test statistics suggest that at $5 \%$ of significance level we accept a zero hypothesis that number of cointegration equations equals zero. The coefficient with real interest rates differential again has the expected positive sign, while negative estimation with NIIP differential, as in the case of the EG test, is confronted to theoretical expectations.

Hence, during the research we have not managed to reveal any empirical support for the models which were in the focus of our attention. In addition, it seems that it is very important to stress two important reasons which may, at least partially, influence such results. Firstly, time series based on which we conducted the test, due to availability of consistent data, are not long enough and they pertain to the period of only four years. Short time series may affect the stability and credibility of the obtained coefficients, and our results should therefore be accepted with certain level of reserve. The research with higher degree of reliability could be implemented only once we have much longer time series. The second reason which can be responsible for such results can be hidden in the fact that transmission of the impact of relative labour productivity in the open and closed sectors to the real exchange rate is implemented through relative prices for non-tradable goods, and that prices of some significant services (which we treated as non-tradable goods) are still under the administrative control. The control of prices could reduce the effectiveness of previously mentioned transmission mechanism. However, despite these inevitable lacks, we deem that results of our research, at least for now, are indicative enough, so they can be understood as preliminary knowledge about the ability of the observed models to describe trend of real exchange rate between RSD and Euro.

\section{Conclusion}

The focus of this research includes the most important determinants of real exchange rate covered by different theoretical models. Empirical testing was conducted on the real exchange rate between RSD and Euro for the period between January 2007 and December 2010, which was greatly imposed by availability of consistent time series. During the research, we tested five basic model specifications, which due to different ways of sector classification into open and closed ones, resulted in evaluation of eight cointegration equations.

Testing of time series cointegration by applying Johnasen and EngleGranger's test, we have not managed to reveal empirical support for any of the observed models. The application of the EG test implies that in all cases at $5 \%$ significance level, we accept a zero hypothesis that time series are not 
Petrović: Testing of empirical grounds for theoretical models of real exchange rate...

cointegrated. Besides, the majority of estimated cointegration coefficients (except for real interest rates differential) have sign contrary to theoretical expectations. Using the Johansen's test, also, we either did not manage to reject the zero hypothesis that number of cointegration equations equals zero, or we have revealed the existence of higher number of equilibrium relations which do not correspond to our models specifications, and do not have theoretical support.

We have doubts that the two reasons could influence such results. The first one addresses the fact that time series we used in the research are not long enough because, due to availability of consistent data, they refer to the period of only four years. The second reason could be the one that transmission of impact of relative labour productivity in the open and closed sector to real exchange rate is realised through prices for non-tradable goods (the BS effect), which can be problematic, since prices for some significant services (nontradable goods) are still under the administrative control. Yet, despite the stated lacks, we deem that our results are quite indicative, i.e. they can be accepted as preliminary knowledge about the ability of the observed models to explain the dynamics of real exchange rate between RSD and Euro.

\section{References}

Alquist, R., \& Chinn, M.D. (2002). Productivity and the Euro-Dollar Exchange Rate Puzzle. National Bureau of Economic Research Working Paper 8824.

Bailey, A., Millard. S., \& Wells S. (2001). Capital flows and exchange rates. Bank of England. Quarterly Bulletin, 41(3): 310-318.

Bayram, T. (2007). Balassa-Samuelson Model Revisited: Growth Productivity Effect \& Capital Accumulation. International Research Journal of Finance and Economics, 9: 144-159.

Brada, J. C., Kutan, M. A., \& Zhou, S. (2002). Real and Monetary Convergence within the European Union and Between the European Union and Candidate Countries: A Rolling Cointegration Approach. William Davidson Working Paper Number 458.

Breuss, F. (2003). Balassa-Samuelson Effects in the CEEC: Are they Obstacles for Joining the EMU? Research Institute for European Affairs Working Paper Nr. 52.

Buiter, W. H., \& Grafe, C. (2002). Anchor, Float or Abandon Ship: Exchange Rate Regimes for the Accession Countries. Retrieved from http://www.nber.org/ wbuiter/eib.pdf

Byrne, J. P., \& Nagayasu, J. (2010). Structural breaks in the real exchange rate and real interest rate relationship. Global Finance Journal, 21: 138-151.

Camarero, M., Ordóñez, J., \& Tamarit, C. (2002). The Euro-Dollar exchange rate: Is it fundamental? European Economy Group Working Paper no. 16/2002.

Camarero, M. (2008). The real exchange rate of the dollar for apanel of OECD countries: Balassa-Samuelson or distribution sector effect? Journal of Comparative 
Petrović: Testing of empirical grounds for theoretical models of real exchange rate...

Economics 36: 620-632.

Choudhri, E. U., \& Khan, S. M. (2004). Real Exchange Rates In Developing Countries: Are Balassa-Samuelson Effects Present? International Monetary Fund Working Paper WP/04/188.

Coudert, V. (2004). Measuring the Balassa-Samuelson effect for the Countries of Central and Eastern Europe? Banque de France Monthly Digest No. 122: 23-43.

De Broeck, M., \& Slok, T. (2001). Interpreting Real Exchange Rate Movements in Transition Countries. BOFIT Discussion Paper Series No. 7/2001.

De Grauwe, P., \& Skudelny, F. (2002). Inflation and productivity differentials in EMU, in Hairault, J.O, H. Kempf (eds.), Market Imperfections and Macroeconomic Dynamics: $77-104$.

Drine, I., \& Rault, C. (2003). A re-examination of the Balassa-Samuleson hypothesis using recent panel data unit-root and cointegration tests: Evidence from MENA countries. Retrieved from http://membres.multimania.fr/drineimed/hpbimg/papier10.pdf

Égert, B., Drine, I., Lommatzsch, K., \& Rault, C. (2002). The Balassa-Samuelson effect in Central and Eastern Europe: Myth or reality? William Davidson Working Paper Number 483.

Égert, B. (2002). Investigating the Balassa-Samuelson hypothesis in transition: Do we understand what we see? BOFIT Discussion Paper Series No. 6.

Fischer, C. (2002). Real currency appreciation in accession countries: BalassaSamuelson and investment demand. Economic Research Centre of the Deutsche Bundesbank Discussion paper 19/02.

Ganelli, G. (2005). The new open economy macroeconomics of government debt. Journal of International Economics, 65: 167-184.

Halpern, L., \& Wyplosz, C. (2001). Economic Transformation and Real Exchange Rates in the 2000s: The Balassa-Samuelson Connection. United Nations Economic Commission for Europe Discussion Paper Series No. 2001.1.

Hoffmann, M., \& MacDonald, R. (2006). A Re-examination of the link between Real Exchange Rates and Real Interest Rate Differentials. Retrieved from http://www.statistik.tudortmund.de/fileadmin/user upload/Lehrstuehle/MSind/SFB 475-B/HoffmannMacDonaldFeb2006.pdf

Jaewoo, L., \& Tang, M.K. (2003). Does Productivity Growth Lead to Appreciation of the Real Exchange Rate? International Monetary Fund Working Paper WP/03/154

Jazbec, B. (2002). Balassa-Samuelson Effect in Transition Economies: The Case of Slovenia. William Davidson Working Paper Number 507.

Jovetić, S., \& Stanišić, N. (2009). The convergence of export structure of European transition economies and EU15 economies with the special overview of the Serbian export structure." Industrija, XXXVII (3): 1-20.

Lojschová, A. (2003). Estimating the Impact of the Balassa-Samuelson Effect in Transition Economies. Retrieved from http://www.ihs.ac.at/publications/eco/es140.pdf

MacDonald, R., \& Ricci, L. (2001). PPP and the Balassa Samuelson Effect: The Role of the Distribution Sector. International Monetary Fund Working Paper WP/01/38.

MacDonald, R., \& Ricci, L. (2005). The real exchange rate and the Balassa Samuelson Effect: The Role of the Distribution Sector. Retrieved from http://www.bancentral.gov.do/trabajos investigacion/paperNo09.pdf 
Petrović: Testing of empirical grounds for theoretical models of real exchange rate...

MacKinnon, J. G. (2010). Critical Values for Cointegration Tests. Queen's Economics Department Working Paper No. 1227.

Mihaljek, D. (2002). The Balassa-Samuelson effect in central Europe: a disaggregated analysis. Paper presented at the conference Exchange rate strategies during the EU enlargement, Budapest.

Mulraine, M. L. B. (2006). Real Exchange Rate Dynamics With Endogenous Distribution Costs. Retrieved from http://homes.chass.utoronto.ca/ mulraine/ERD.pdf

Nikolić, I., \& Zdravković, M. 2009. Revision of the State Budget of the Republic of Serbia for 2009. Industrija, XXXVII (4): 103-112.

Popova, J., \& Tkachevs. O. (2004). On the Balassa-Samuelson Effect in Latvia. Paper presented at the Young Researchers Enlargement Conferences, Centre for European and Transition Studies.

Schnatz, B., Vijselaar F., \& Osbat. C. (2004). Productivity and the Euro-Dollar Exchange Rate. Review of World Economics, 140(1): 1-30.

Tica, J., \& Družić, I. (2006). The Harrod-Balassa-Samuelson Effect: A Survey of Empirical Evidence. EFZG Working Papers Series No 607.

Tille, C., Stoffels, N., \& Gorbachev, O. (2001). To what extent does productivity drive the dollar? Current Issues in Economics and Finance, 7 (8): 1-6.

Timmer, M.P., \& Inklaar, R. (2005). Productivity differentials in the U.S. and EU distributive trade sector: Statistical myth or reality? CCSO Working paper 2005/01. 